\title{
Translational control of an intestinal microvillar enzyme
}

\author{
E. Michael DANIELSEN, Gillian M. COWELL, Hans SJÖSTRÖM and Ove NORÉN \\ Department of Biochemistry C, The Panum Institute, University of Copenhagen, Copenhagen, Denmark
}

\begin{abstract}
The rates of biosynthesis of adult and foetal pig small-intestinal aminopeptidase N (EC 3.4.11.2) were compared to determine at which level the expression of the microvillar enzyme is developmentally controlled. In organ-cultured explants, the rate of biosynthesis of foetal aminopeptidase $\mathrm{N}$ is only about $3 \%$ of the adult rate. The small amount synthesized occurs in a high-mannose-glycosylated, membrane-bound, form that is processed to the mature, complex-glycosylated, form at a markedly slower rate than that of the adult enzyme. Extracts of total RNA from adult and foetal intestine contained comparable amounts of aminopeptidase $\mathrm{N}$ mRNA, encoding gel-electrophoretically identical primary translation products. Together, these data indicate that the expression of aminopeptidase $\mathbf{N}$ is controlled at a translational level.
\end{abstract}

\section{INTRODUCTION}

Aminopeptidase N (EC 3.4.11.2) is one of the major integral hydrolases of the microvillar membrane of the small intestine, participating in the final digestion of nutrients. This group of enzymes is commonly referred to as 'stalked' membrane proteins, owing to their characteristic membrane topology (Kenny \& Maroux, 1982; Norén et al., 1986). Aminopeptidase $\mathrm{N}$ from adult individuals is synthesized by ribosomes attached to the rough endoplasmic reticulum, where membrane translocation and insertion, together with $N$-linked highmannose glycosylation, takes place. Intracellular transport to the extracellular site of function proceeds in a membrane-bound state, and the route passes through the Golgi complex, where carbohydrate processing occurs to yield the mature form of the enzyme (Danielsen et al., 1984).

It is well known that the activity of microvillar enzymes, including aminopeptidase $\mathbf{N}$, increases during embryonic and/or early postnatal development, and that glucocorticoids and thyroxine play a major role in inducing or stimulating their expression (Moog, 1979; Kedinger et al., 1980; Henning, 1981). This process is a part of the overall cellular differentiation that leads to the formation of the highly polarized enterocyte, and a study of the mechanisms controlling this differentiation is essential for the understanding of how cell polarity is generated. This paper reports a comparison of the rate of biosynthesis of aminopeptidase $\mathrm{N}$ in adult and foetal small intestine, a work performed to determine at what level the expression of this microvillar enzyme is controlled.

\section{MATERIALS AND METHODS}

\section{Materials}

Equipment for performing organ culture, including Trowell's T-8 medium, foetal-calf serum, sterile plastic dishes with grids and $\left[{ }^{35} \mathrm{~S}\right]$ methionine (specific radioactivity $>1000 \mathrm{Ci} / \mathrm{mmol}$ ), were obtained as previously described (Danielsen et al., 1982a). Dog pancreatic microsomal membranes were purchased from Amersham International, Amersham, Bucks., U.K.

Pig adult and foetal small intestines were kindly given by the Department of Experimental Pathology, Rigshospitalet, Copenhagen, Denmark, and De Forenede Andelsslagterier, Ringsted, Denmark, respectively.

\section{Methods}

Organ culture of intestinal mucosal explants was performed as described by Danielsen et al. (1982a) and preparation of intestinal RNA and cell-free translation in a reticulocyte lysate system were as described by Danielsen et al. (1982b). Enzymes were purified by line-immunoelectrophoresis (Danielsen \& Cowell, 1983). SDS/polyacrylamide-gel electrophoresis was performed as described by Laemmli (1970), and fluorography of gels by the method of Bonner \& Laskey (1974).

\section{RESULTS}

Organ culture of intestinal explants is a well-established technique for maintaining both adult (Browning \& Trier, 1969) and foetal (Simon-Assmann et al., 1982) tissue for periods up to $48 \mathrm{~h}$. We have previously adapted organ culture for pig small-intestinal explants and have shown that the morphology, at both the light- and the electron-microscopic level, is well preserved during culture up to $24 \mathrm{~h}$ (Danielsen et al., 1982a). The explants also maintained their contents of protein and microvillar enzymes and were able to sustain a continuous protein synthesis during the entire culture period. The explant system has since been used to study the nature and kinetics of microvillar-enzyme biosynthesis in adult intestine (for review, see Danielsen et al., 1984). The second system used, cell-free translation of total RNA from small intestine, has previously been used to gain information about the primary translation product of aminopeptidase $\mathrm{N}$ and its co-translational processing by microsomal membranes (Danielsen et al., 1982b, 1983).

Fig. 1 shows the polypeptide pattern of membranebound and soluble fractions of organ-cultured adult and foetal explants labelled for $5 \mathrm{~h}$. The fuzzy $M_{\mathrm{r}}-166000$ polypeptide of mature aminopeptidase $\mathrm{N}$, which is a predominant component in the adult membrane-bound fraction, was not apparent in foetal tissue. As shown in Table 1, the enzyme only comprises $0.026 \%$ of the total protein synthesized in foetal explants, compared with $0.80 \%$ in adult tissue, indicating that the rate of synthesis 


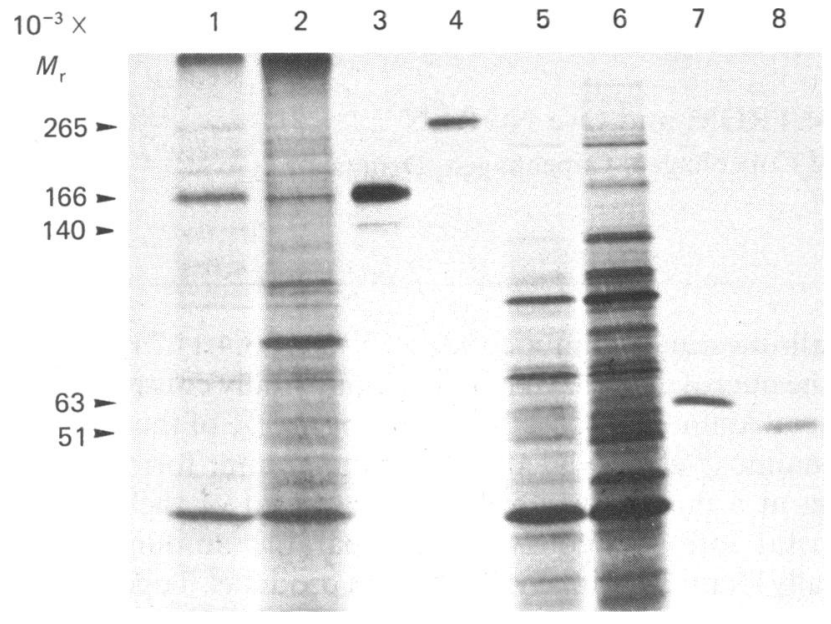

Fig. 1. Biosynthesis in organ-cultured adult and foetal explants

The explants were labelled for $5 \mathrm{~h}$ with $100 \mu \mathrm{Ci}$ of ${ }^{\left[{ }^{35} \mathrm{~S}\right]}$ methionine/ml and homogenized in $1 \mathrm{ml}$ of $5 \mathrm{mM}$-Tris/ $/ \mathrm{HCl}$ (pH 7.5)/150 mM- NaCl with a Potter-Elvehjem homogenizer. The homogenates were centrifuged at $100000 \mathrm{~g}$ for $1 \mathrm{~h}$ in a Beckman Airfuge to obtain a pellet (membranebound fraction) and a supernatant (soluble fraction). Samples of these fractions were subjected to SDS/polyacrylamide gel electrophoresis. Apparent $M_{\mathrm{r}}$ values are shown. Tracks: 1, adult membrane-bound fraction; 2, foetal membrane-bound fraction; 3, immunopurified transient $\left(M_{\mathrm{r}} 140000\right)$ and mature $\left(M_{\mathrm{r}} 166000\right)$ forms of adult aminopeptidase $\mathrm{N} ; 4$, immunopurified adult sucraseisomaltase; 5 , adult soluble fraction; 6 , foetal soluble fraction; 7, immunopurified adult proline dipeptidase; 8 , immunopurified adult glycyl-leucine dipeptidase.

of aminopeptidase $\mathbf{N}$ during development from the foetal to the adult state is increased about 30 -fold. This result was also obtained with labelling periods as short as $10 \mathrm{~min}$ and in the presence of the proteinase inhibitor leupeptin, arguing against the possibility that the low amount of aminopeptidase $\mathrm{N}$ synthesized in foetal explants can be ascribed to a rapidly occurring post-translational degradation of newly synthesized enzyme, as has been observed in adult explants organ-cultured in the presence of tunicamycin (Danielsen $\&$ Cowell, 1984). The molecular forms of foetal aminopeptidase $\mathrm{N}$ were membrane-bound and of similar $M_{\mathrm{r}}$ to the adult transient high-mannose-glycosylated $\left(M_{\mathrm{r}}\right.$ $140000)$ and mature complex-glycosylated $\left(M_{\mathrm{r}} 166000\right)$ forms of the enzyme (Fig. 2). However, the rate of conversion of the foetal transient form of aminopeptidase $\mathrm{N}$ into the mature form was very slow; the latter could not be detected after $1.5 \mathrm{~h}$ of labelling, whereas it appears after about $30 \mathrm{~min}$ in adult explants (Danielsen, 1982) (Fig. 2). Furthermore, the amount of mature form relative to the amount of transient form after $3 \mathrm{~h}$ of labelling was about one order of magnitude less than previously observed for the adult tissue (Danielsen \& Cowell, 1985) (as judged by densitometric scanning of the fluorograph), indicating that the rate of conversion of aminopeptidase $\mathbf{N}$ in foetal tissue is 4-5 times slower. However, after longer periods of labelling (up to $14 \mathrm{~h}$ ), the relative intensity of the mature form greatly increased, indicating that, although it is generated at a slower rate, it is the quantitatively predominant molecular form present in foetal, as well as in adult, intestine.

Two cytosolic dipeptidases, glycyl-leucine dipeptidase (EC 3.4.13.11) (Norén et al., 1973) and proline dipeptidase (EC 3.4.13.9) (Sjöström et al., 1973), were also found to have a much lower rate of biosynthesis in foetal than in adult tissue $(0.006 \%$ versus $0.092 \%$ and $0.026 \%$ versus $0.190 \%$, respectively).

mRNA from guanidinium chloride extracts of total RNA of adult and foetal small intestine was observed to encode primary translation products of aminopeptidase $\mathrm{N}$ that are gel-electrophoretically identical $\left(M_{\mathrm{r}} 115000\right)$ (Fig. 3). The similar relative amounts of aminopeptidase $\mathbf{N}$ synthesized by the cell-free translation system (Table 1) indicate that adult and foetal small intestine contain comparable relative amounts of mRNA encoding the enzyme. Glycyl-leucine dipeptidase (Fig. 3) and proline dipeptidase (results not shown) were also synthesized in

Table 1. Synthesis of adult and foetal aminopeptidase $\mathbf{N}$ in organ-cultured intestinal explants and by intestinal $\mathrm{mRNA}$ in cell-free translation

Explants of adult and foetal small intestine were labelled continuously for $5 \mathrm{~h}$ with $100 \mu \mathrm{Ci}$ of $\left[{ }^{35} \mathrm{~S}\right] \mathrm{methionine} / \mathrm{ml}$. The radioactivity incorporated into both adult and foetal explants was about $10^{6} \mathrm{c.p} . \mathrm{m} . / \mathrm{mg}$ of explant protein. After culture, the explants were solubilized in $1 \mathrm{ml}$ of $5 \mathrm{~mm}-\mathrm{Tris} / \mathrm{HCl}(\mathrm{pH} 7.5) / 150 \mathrm{mM}-\mathrm{NaCl} / 5 \%(\mathrm{v} / \mathrm{v})$ Triton X-100. After $15-30 \mathrm{~min}$ on ice with frequent vortex-mixing, the homogenate was centrifuged for $1 \mathrm{~min}$ in a Beckman Microfuge to obtain a supernatant of extracted protein. For cell-free translation, the translation mixtures $(280 \mu \mathrm{l})$ contained $100 \mu \mathrm{l}$ of nuclease-treated rabbit reticulocyte lysate, $100 \mu \mathrm{Ci}$ of $\left[{ }^{35} \mathrm{~S}\right]$ methionine and guanidinium chloride extracted adult or foetal intestinal RNA in amounts yielding maximal incorporation of radioactivity into protein $(3000-6000$ c.p.m./ $\mu 1$ of translation mixture). In both explant and cell-free translation experiments, total protein synthesis was determined as trichloroacetic acid-precipitable radioactivity (measured in $10 \mu \mathrm{l}$ samples), and aminopeptidase $\mathrm{N}$ synthesis was determined by measuring the radioactivity incorporated into the carefully washed immunoprecipitate. The synthesis of aminopeptidase $\mathrm{N}$ is expressed as $100 \times$ radioactivity of aminopeptidase $\mathrm{N} /$ radioactivity of trichloroacetic acid precipitate. Foetuses of $14-20 \mathrm{~cm}$ in length were used, and each value listed is the mean of three to five experiments.

Aminopeptidase $\mathrm{N}$ synthesis

(\% of total protein synthesis)

\begin{tabular}{lll}
\cline { 2 - 3 } \multicolumn{1}{c}{ Type of experiment } & Adult & Foetal \\
\hline Organ culture of explants & 0.80 & 0.026 \\
Cell-free translation of mRNA & 0.18 & 0.19
\end{tabular}




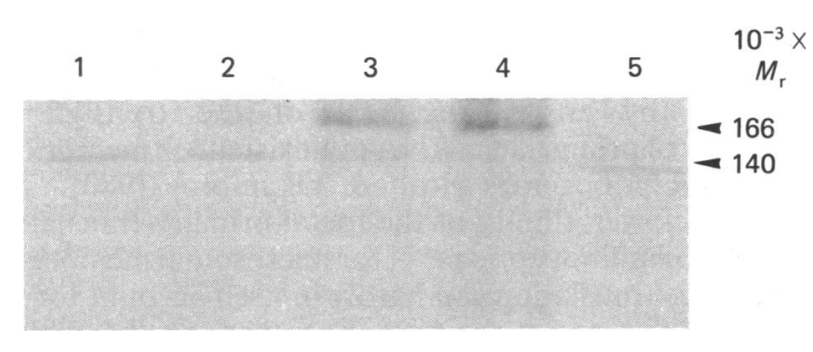

Foetal explants were labelled with $200 \mu \mathrm{Ci}$ of

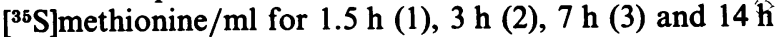
(4), and after culture, aminopeptidase $\mathrm{N}$ was purified from Triton X-100 extracts as described in the legend to Table 1. The purified enzyme was subjected to SDS/polyacrylamide-gel electrophoresis (apparent $M_{\mathbf{r}}$ values are shown). Track 5 shows the transient form of adult aminopeptidase $\mathrm{N}$ for comparison.

relative comparable amounts by mRNA from adult and foetal intestine.

The properties of adult and foetal mRNA encoding aminopeptidase $\mathrm{N}$ were further compared by supplementing the cell-free translation system with microsomal membranes. For adult mRNA, microsomal membranes have previously been shown to process the primary translation product of aminopeptidase $\mathrm{N}$ into an

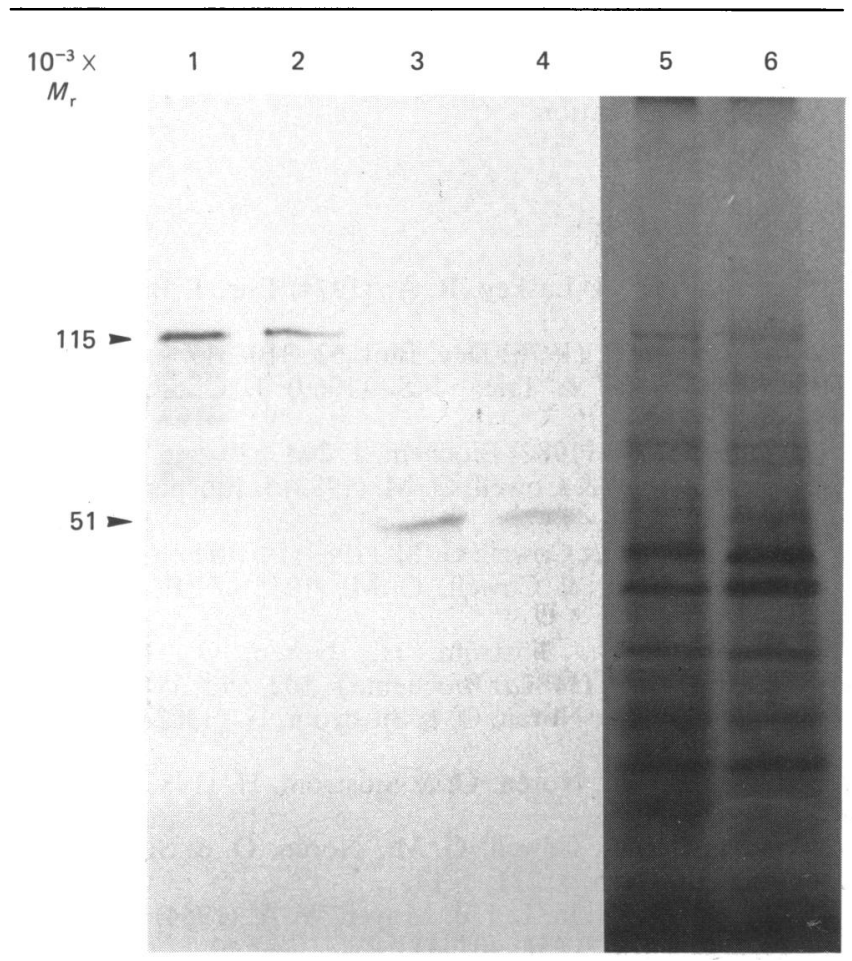

Fig. 3. Cell-free translation of adult and foetal intestinal mRNA

SDS/polyacrylamide-gel electrophoresis of immunopurified adult and foetal aminopeptidase $\mathbf{N}$ and glycyl-leucine dipeptidase from cell-free translation of intestinal mRNA (apparent $M_{\mathrm{r}}$ values are shown). Tracks: 1, adult aminopeptidase $\mathrm{N} ; 2$, foetal aminopeptidase $\mathrm{N} ; 3$, adult glycyl-leucine dipeptidase; 4 , foetal glycyl-leucine dipeptidase; 5 , adult total translation products; 6 , foetal total translation products.

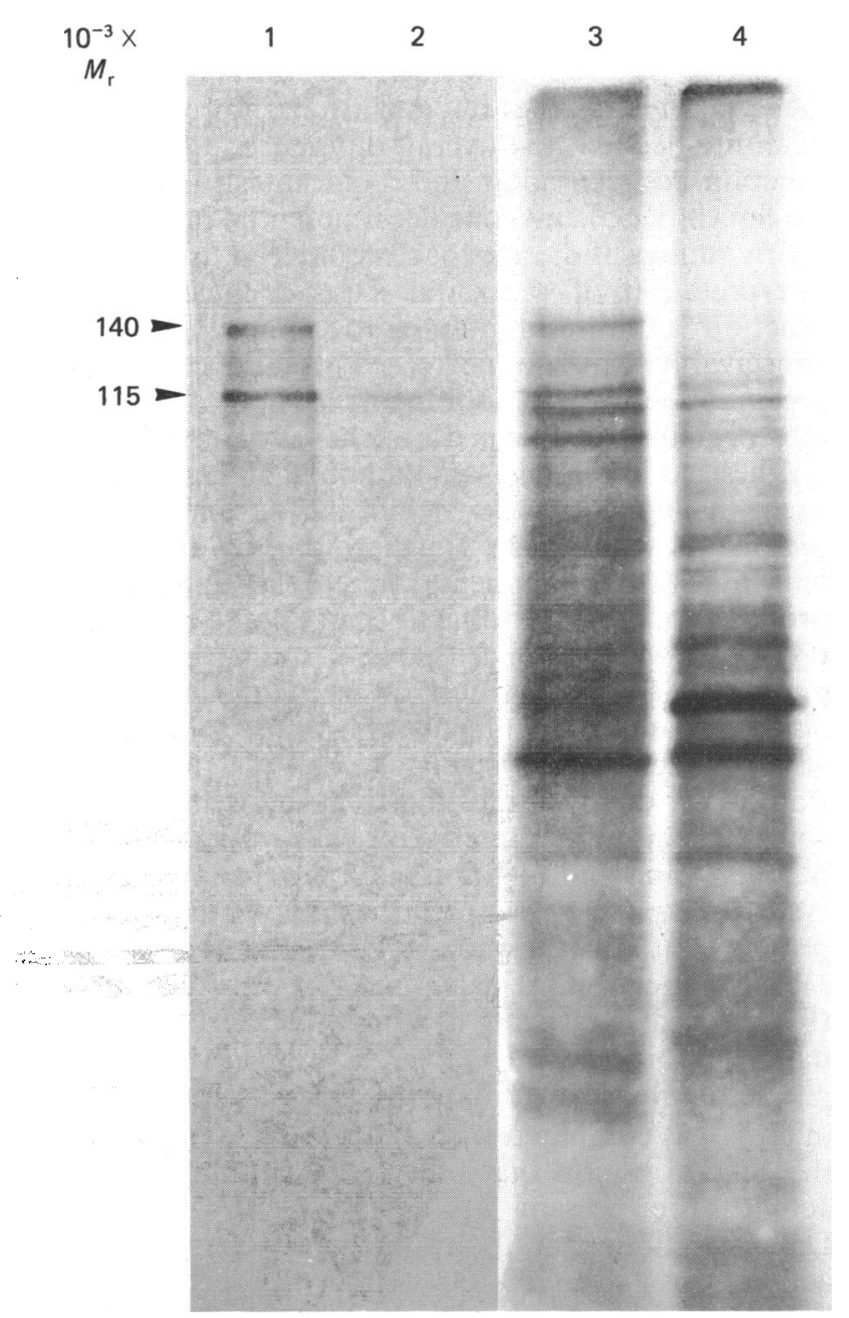

Fig. 4. Processing of primary translation products by microsomal membranes

SDS/polyacrylamide-gel electrophoresis of immunopurified adult and foetal aminopeptidase $\mathrm{N}$ from cell-free translation of intestinal mRNA in the presence of microsomal membranes (apparent $M_{\mathrm{r}}$ values are shown). Tracks: 1 , adult aminopeptidase $\mathrm{N} ; 2$, foetal aminopeptidase $N$; 3 , adult total translation products; 4 , foetal total translation products.

endoglycosidase H-sensitive polypeptide of $M_{\mathrm{r}} 140000$, identical with the transient form of the enzyme from organ-cultured explants (Danielsen et al., 1983). As shown in Fig. 4, microsomal membranes likewise glycosylated the primary translation product of foetal mRNA. However, in parallel incubations, the microsomal membranes processed the foetal primary translation product with only about half the efficiency of that with which the adult $M_{\mathrm{r}}-115000$ polypeptide was glycosylated and did not stimulate its translation, as observed for the adult enzyme (judged by densitometric scanning of fluorographs).

\section{DISCUSSION}

The combined use of an explant system and cell-free translation in a comparative study on the biosynthesis of adult and foetal aminopeptidase $\mathbf{N}$ should be able to 
give information about the level at which the expression of the enzyme is controlled during embryonic development. Before drawing any conclusions, however, one must take into account the overall difference in structure and function between adult and foetal intestine (for review, see Smith, 1985) and consider if potential inaccuracies or shortcomings of the approach could lead to an erroneous interpretation of the data. Thus a lower absorptive function of the immature foetal epithelium might conceivably cause a decreased uptake of radioactive precursor, leading to poor incorporation of radioactivity into protein. As it turned out, however, foetal explants synthesized about the same amount of protein as adult tissue, as judged by the trichloroacetic acid-precipitable radioactivity (Table 1). Furthermore, by expressing the biosynthesis of aminopeptidase $\mathrm{N}$ relative to the overall protein synthesis, any difference in uptake of radioactive precursor will be cancelled as a source of error. The multi-cellular composition of intestinal mucosa could also be thought to influence the results obtained, both with the explant system as well as with cell-free translation of total intestinal RNA, for instance if the contribution by non-epithelial cells varies significantly between adult and foetal tissue. However, in the explant system the polypeptide pattern of total adult and foetal protein synthesis showed a high degree of overlap (Fig. $1)$; this was even more pronounced in cell-free translation (Figs. 3 and 4), arguing against this possibility being of major importance.

The very low rate of biosynthesis of aminopeptidase $\mathrm{N}$ in foetal, as compared with adult, tissue agrees well with the general notion that only small amounts of enzyme activity are present at this stage of development. Determinations of antibody-suppressible aminopeptidase activity in Triton X-100 extracts of foetal intestine likewise indicate a low amount of enzyme compared with adult values (results not shown). The fact that the foetal enzyme is membrane-bound and occurs in molecular forms characteristic of a 'normal' co- and posttranslational processing is evidence that the expression of aminopeptidase $\mathbf{N}$ is controlled at a stage before polypeptide synthesis. Surprisingly, adult and foetal intestine contain comparable amounts of mRNA for aminopeptidase $\mathrm{N}$, arguing against the possibility of a transcriptional control. Taken together, the data from organ culture and cell-free translation experiments indicate that the mechanism that controls the expression of aminopeptidase $\mathbf{N}$ operates at a translational level. A similar finding has not previously been reported for a microvillar enzyme; in fact, it has been suggested that sucrase-isomaltase (EC 3.2.1.48-3.2.1.10) and maltaseglucoamylase (EC 3.2.1.20) are regulated at a transcriptional level (Simon-Assmann et al., 1984). However, in that study, which reported the effect of actinomycin D on microvillar enzyme activities in organ-cultured rat small-intestinal explants, the culture period was of a length comparable with the life-span of the cells $(48 \mathrm{~h})$, obscuring a clear-cut interpretation of the data.

Translational control of protein expression is a phenomenon known from other organisms, most notably the sea urchin in its early embryonic development (Gross et al., 1964), where the overall rate of protein synthesis increases after fertilization (Brandhorst, 1976). Examples of a more selective type of translational control have been reported to occur in higher organisms (Shull \& Theil, 1982; Maundrell et al., 1983; McGuire et al., 1984). For proinsulin, it has been suggested that its biosynthesis induced by glucose in pancreatic islets of the rat is mainly achieved by an enhancement of the translational efficiency of proinsulin mRNA pre-existent on membranebound polyribosomes (Itoh \& Okamoto, 1980): The observed lower affinity of the foetal primary translation product of aminopeptidase $\mathbf{N}$ for microsomal membranes in cell-free translation can hardly in itself account for the 30 -fold difference in the rate of synthesis in the explant system, but could be suggestive of a structural difference between adult and foetal mRNA species. Likewise, the markedly slower rate of conversion of the foetal enzyme from the transient into the mature form is indicative of a slow rate of migration from the rough endoplasmic reticulum into (and through) the Golgi complex, and could be suggestive of a minor structural difference between adult and foetal primary translation products, altering the 'signals' for processing and intracellular transport (Sabatini et al., 1982). Alternatively, this phenomenon may reflect a poorly developed pathway for processing and transport of newly synthesized plasmamembrane proteins in foetal tissue. The results with the two cytosolic dipeptidases indicate that translational control might be a general phenomenon in the expression of proteins that have a similar developmental pattern, be they membrane-bound or soluble. The mechanism whereby this translational control is achieved is as yet unknown, but is an attractive subject for further study.

E.M.D. was supported by a 'Hallas-Møller'-stipend from the Novo Foundation and G.M.C. by a grant from the Weimann Foundation.

\section{REFERENCES}

Bonner, W. M. \& Laskey, R. A. (1974) Eur. J. Biochem. 46, 83-88

Brandhorst, B. P. (1976) Dev. Biol. 52, 310-317

Browning, T. H. \& Trier, J. S. (1969) J. Clin. Invest. 48, 1423-1432

Danielsen, E. M. (1982) Biochem. J. 204, 639-645

Danielsen, E. M. \& Cowell, G. M. (1983) J. Biochem. Biophys. Methods 8, 41-47

Danielsen, E. M. \& Cowell, G. M. (1984) FEBS Lett. 166, 28-32

Danielsen, E. M. \& Cowell, G. M. (1985) FEBS Lett. 190, 69-72

Danielsen, E. M., Sjöström, H., Norén, O., Bro, B. \& Dabelsteen, E. (1982a) Biochem. J. 202, 647-654

Danielsen, E. M., Norén, O. \& Sjöström, H. (1982b) Biochem. J. 204, 323-327

Danielsen, E. M., Norén, O. \& Sjöström, H. (1983) Biochem. J. 212, 161-165

Danielsen, E. M., Cowell, G. M., Norén, O. \& Sjöström, H. (1984) Biochem. J. 221, 1-14

Gross, P. R., Malkin, L. I. \& Moyer, W. A. (1964) Proc. Natl. Acad. Sci. U.S.A. 51, 407-411

Henning, S. J. (1981) Am. J. Physiol. 241, G199-G214

Itoh, N. \& Okamoto, H. (1980) Nature (London) 283, 100-102

Kedinger, M., Simon, P. M., Raul, F., Grenier, J. F. \& Haffen, K. (1980) Dev. Biol. 74, 9-21

Kenny, A. J. \& Maroux, S. (1982) Physiol. Rev. 62, 91-128

Laemmli, U. K. (1970) Nature (London) 227, 680-685

Maundrell, K., Imaizumi-Scherrer, M. T., Maxwell, E. S., Civelli, O. \& Scherrer, K. J. (1983) J. Biol. Chem. 258, 1387-1390

McGuire, D. M., Olson, C. D., Towle, H. C. \& Dempsey, M. E. (1984) J. Biol. Chem. 259, 5368-5371 
Moog, F. (1979) J. Anim. Sci. 49, 239-249

Norén, O., Sjöström, H. \& Josefsson, L. (1973) Biochim. Biophys. Acta 327, 446-456

Norén, O., Sjöström, H., Danielsen, E. M., Cowell, G. M. \& Skovbjerg, H. (1986) in The Molecular and Cellular Biology of Digestion (Desnuelle, P., Sjöström, H. \& Norén, O., eds.), Elsevier, Amsterdam, in the press

Sabatini, D. D., Kreibich, G., Morimoto, T. \& Adesnik, M. (1982) J. Cell Biol. 92, 1-22
Shull, G. E. \& Theil, E. C. (1982) J. Biol. Chem. 257, 14187-14191

Simon-Assmann, P. M., Kedinger, M., Grenier, J. F. \& Haffen, K. (1982) J. Pediatr. Gastroenterol. Nutr. 1, 257-265

Simon-Assmann, P., Kedinger, M., Grenier, J. F. \& Haffen, K. (1984) Enzyme 31, 65-72

Sjöström, H., Norén, O. \& Josefsson, L. (1973) Biochim. Biophys. Acta 327, 457-470

Smith, M. W. (1985) Annu. Rev. Physiol. 47, 247-260

Received 28 October 1985/2 December 1985; accepted 10 December 1985 